\title{
Pertanggungjawaban Publik Pemerintah dalam Perspektif Hukum Administrasi Negara
}

\section{Ridwan}

\begin{abstract}
One of principle in democratic legal state is legality, where every legal goverment action should be based on the authority mandated by regulation. Political and juridical accountability of authority holder is inherent with every form of goverment authority use; according with principle that no authority without accountability (geen behoegheid zonder verantwoordelijkheid)
\end{abstract}

\section{Pendahuluan}

Salah satu aspek penting dalam negara hukum demokratis (democratische rechtsstaat)' adalah asas legalitas (legaliteitsbeginsel), yang mengandung makna bahwa setiap tindakan hukum pemerintah harus didasarkan pada peraturan perundang-undangan yang berlaku atau didasarkan pada kewenangan yang diberikan oleh peraturan yang berlaku. Kewenangan ini mengandung makna het vermogen tot het verrichten van bepaalde rechtshandelinge", ${ }^{2}$ yaitu kemampuan untuk melakukan tindakan-tindakan hukum tertentu. Dalam hukum publik, kewenangan (bevoegdheid) dianggap sebagai konsep inti dalam hukum tata negara dan hukum administrasi negara het begrip bevoegdheid is dan ook een kernbegrip in het staats-en administratief recht. ${ }^{3}$ Berdasarkan kewenangan

'Secara sederhana, negara hukum demokratis adalah negara yang mengakomodir prinsip-prinsip negara hukum dan prinsip-prinsip demokrasi, lihat H.D. van WijkWillem Konijnenbelt, Hoofdstukken van Administratief Recht (Utrecht: Uitgeverij Lemma BV. 1995), hlm. 41-49, dan J.B.J.M. ten Berge, Besturen Door De Overheid. Deventer: W.E.J. Tjeenk Willink, 1996), hlm. 34-38. Asas legalitas merupakan perwujudan dari prinsip negara hukum, yang mengedepankan hukum tertulis sebagai dasar bertindak bagi pemerintah, dan prinsip demokrasi, yang bertumpu pada partisipasi rakyat yang secara formal dituangkan dalam bentuk undang-undang atau hukum tertulis.

2P. Nicolai, et, al, Bestuursrecht. Amsterdam (1994), hlm. 4.

${ }^{3}$ Stroink, F.A.M., en J.G. Steenbeek, Inleiding in het Staaten Administratief Recht (Alphen aan den Rijn: Samsom H.D. Tjeenk Willink, 1985), him. 26. 
inilah pemerintah memiliki keabsahan baik secara politis maupun yuridis untuk melakukan berbagai tindakan hukum (rechtshandelingen), dan berdasarkan kewenangan itu pula muncul prinsip pertanggungjawaban pemerintah; niemand kan een bevoegdheid uitoefenen zonder verantwording schuldig te zijn of zonder dat of die uitoefening controle bestaant (tidak seorangpun dapat melaksanakan kewenangan tanpa memikul kewajiban tanggungjawab atau tanpa ada pelaksanaan pengawasan). Dengan kata lain, geen bevoegdheid zonder verantwoordelijkheid atau there is no authority without responsibility. Karena kewenangan pemerintahan itu pada dasamya berasal dari undang-undang, yang merupakan kristalisasi dari aspirasi rakyat (demokrasi) dan sebagai salah satu pilar negara hukum, maka pertanggungjawaban publik dari pemegang kewenangan akan bertentuk pertanggungjawaban yuridis dan politis serta pengawasan yuridis melalui badan peradilan dan pengawasan politik melalui badan perwakilan rakyat. Meskipun demikian, tulisan ini lebih menekankan pada pertanggungjawaban dan pengawasan yuridis.

Berdasarkan proposisi di atas, tulisan ini akan menggunakan contoh kasus dengan membidik putusan Pengadilan Negeri Jakarta Pusat No. 449/PID.B/2002/PN.JKT.PST, yang antara lain memutuskan pidana penjara selama 3 (tiga) tahun terhadap mantan Menteri Sekretaris Negara (Mensesneg). Dengan mengacu pada proposisi tadi, putusan pengadilan tersebut memuat persoalan hukum (kwestierecht), khususnya hukum administrasi, karena kasus ini berkenaan dengan kewenangan -yang merupakan konsep inti dalam hukum administrasi. Persoalan hukum yang muncul adalah; apakah Mensesneg mamiliki kewenangan dan telah menyalahgunakannya sehingga dikenai putusan seperti itu? Bukankah Mensesneg saat itu bertindak atas nama Presiden, selaku pemegang kewenangan yang sesungguhnya? Bagaimanakah hubungan hukum (rechtsbetrekking) antara Presiden dengan Menteri? Lebih lanjut, siapakah yang seharusnya bertanggungjawab atas pelaksanaan kewenangan pemerintahan yang kebetulan dijalankan oleh Mensesneg tersebut?

Telah diketahui sejak awal kemunculannya, kasus ini telah banyak menarik perhatian bukan saja para ahli hukum dan para politisi tetapi juga masyarakat luas. Perhatian yang terkesan berlebihan terhadap kasus ini agaknya bukan hanya karena kasus ini melibatkan tokoh penting negeri ini, tetapi juga karena melibatkan banyak aspek di dalamnya seperti aspek pidana, tata negara, politik, dan aspek administrasi negara. Tanpa berpretensi untuk terlibat apalagi mempengaruhi proses peradilan yang telah dan masih akan berlangsung, tulisan ini sekadar mengkaji kasus tersebut semata-mata dari aspek teoretik, khususnya terhadap kewenangan, penggunaan, dan pertanggungjawabannya berdasarkan ilmu hukum administrasi negara.

Dari perspektif hukum administrasi negara kasus ini berkaitan dengan kewenangan Presiden selaku organ yang menjalankan

4A.D. Belinfante, et.al, Beginselen van Nederlandse Staatsrecht (Alphen aan den Rijn, 1983) Hlm. 21. 
tugas-tugas kenegaraan dan pemerintahan, yang dalam pelaksanaannya dibantu oleh para menteri antara lain Mensesneg. Oleh karena itu $u_{i}$ untuk menganalisis kasus ini harus diketahui terlebih dahulu kewenangan pemerintahan (bestuursbevoegdheid), kedudukan hukum (rechtspositie) Menteri, hubungan hukum (rechtsbetrekking) Menteri dengan Presiden, dan pertanggungjawaban pelaksanaan kewenangan pemerintahan.

\section{Kewenangan Pemerintahan}

Telah disebutkan, salah satu prinsip negara hukum adalah asas legalitas (legaliteitbeginse/), sebagai dasar yang memberikan kewenangan untuk keabsahan melakukan tindakan hukum bagi pemerintah. Dalam negara hukum terutama pada sistem kontinental asas legalitas ini dianut begitu ketat, dalam arti tanpa ada kewenangan yang diberikan oleh peraturan perundangundangan, pemerintah tidak dapat melakukan perbuatan hukum. Meskipun demikian, secara teoretik dan praktik khususnya dalam negara modern hampir tidak mungkin merumuskan fungsi dan kewenangan pemerintahan secara detail dengan menentukannya dalam peraturan perundangundangan, hal ini karena fungsi dan kewenangan pemerintahan berkaitan erat dengan pelayanan terhadap masyarakat yang selalu berkembang. Hal ini dengan sendirinya di dalam tindakan hukum pemerintahan itu selalu tersirat ruang kebebasan (beordelingsruimte) atau penerapan kebijaksanaan, sebagai suatu relaksasi "kekakuan dan keterbatasan" peraturan tertulis. Berbeda dengan tindakan hukum pemerintah di negara hukum kontinental yang begitu ketat berpegang pada asas legalitas, pada negara hukum Anglo Saxon tindakan hukum pemerintah tidak begitu ketat berpegang pada asas legalitas, sebagaimana dapat disimak dari catatan Foulkes di bawah ini: 5

If the govemment has decided on certain action - to give grants and loans to firm, to encourage export, to abolish pay beds in hospitals, to ensure that secondary education is organised on the comprehensive principle, to hold a referendum and so on - it will have to ask itself whether it needs statutory authority to do it. It can do many things without having to rely of such authority. It can enter into contracts, it can conduct foreign affairs and sign treaties, ... It can, like any other employer, $d$. rect the work of employees. It can send troops to Suez and bring them back. It can create new institutions by the grant of a charter or by purely administrative action. All these it can do without having to get the prior consent of partiament whether by Act or otherwise.

Dari keterangan tersebut tampak bahwa dalam negara hukum modern pemerintah dilekati dengan fungsi dan kewenangan yang sangat luas (extremely wide), ${ }^{6}$ dan tidak semuanya dapat ditentukan secara rinci dalam peraturan perundang-undangan. Fungsi dan

5Foulkes, Introduction to Administrative Law Fourt Edition. (London: Butterworts, 1976), hlm. 13.

'Irving Stevens, Constitutional \& Administrative Law (Pitman Publishing, 1996), hlm. 163. 
kewenangan pemerintahan yang sangat luas ini inuncul segera setelah runtuhnya pengaruh liberalisme pada akhir abad ke sembilan belas. Sèbelumnya ketika pengaruh liberalisme masih dominan, dianut prinsip staatsonthouding dalàm bidang pemerintahan dan kenegaraan yang berarti the state should intervene as little as possible in people's lives and businesses. ${ }^{\text {? }}$ Prinsip'ini ternyata membawa dampak yang sangat!destruktif dalam bidang sosial dan ekonomi, sehingga dipikirkan kembali peran pemerintah dalam kehidupan sosial dan ekonomi, yang secara perlahan kepada pemerintah diberikan kekuasaan untuk melakukan intervensi terhadap kehidupan warga negara (staatsbemoeienis). Secara garis besar intervensi pemerintah terhadap warga negara ini muncul dalam dua bentuk yaitu bidang pelayanan (besturing) dan bidang pengaturan (regeling). Tak pelak lagi, pemberian kewenangan intervensi di bidang pengaturan itu secara otomatis memberikan kewenangan kepada pemerintah untuk terlibat dalam pembuatan undang-undang dan kewenangan untuk membuat peraturan perundangundangan mandiri, tanpa keterlibatan badan pembuat undang-undang (legislatif), seperti pembuatan peraturan pemerintah (algemeen matregel van bestuur), keputusan-keputusan (bes/uiten) pemerintah atau pejabat administrasi negara yang mengikat umum, dản lain-lain. Bahkan dalam situasi tertentu kepada pemerintah diberikan kewenangan bebas (discresionary power, freies ermessen), yang jika dituangkan dalam bentuk tertulis akan menjadi peraturan kebijaksanaan (beleidsregel).

$\mathrm{Di}$ Indonesia kewenangan untuk menjalankan pemerintahan ini ada pada Presiden; "Presiden Republik Indonesia memegang kekuasaan pemerintahan menurut Undang-Undang Dasar ${ }^{8}{ }^{8}$ Telah disebutkan, ruang lingkup bidang pemerintahan tidak dapat ditentukan batas-batasnya secara tegas karena berkenaan dengan perkembangan kemasyarakatan yang sangat luas dan beragam yang harus dilayani dan diatur oleh Presiden, oleh karena itu ruang lingkup kewenangan atau kekuasaan Presiden Indonesia juga demikian luas. Luasnya kekuasaan Presiden dalam bidang pemerintahan ini tampak sebagaimana disebutkan Bagir Manan yang membagi kekuasaan penyelenggaraan pemerintahan yang bersifat umum dan yang bersifat khusus. Kekuasaan penyelenggaraan pemerintahan yang bersifat umum adalah kekuasaan menyelenggarakan administrasi negara yang mencakup bidang keamanan dan ketertiban umum, penyelenggaraan tata usaha pemerintahan, bidang pelayanan umum, dan penyelenggaraan kesejahteraan umum, sementara kekuasaan penyelenggaraan pemerintahan yang bersifat khusus adalah

'Lihat AP Le Sueur dan JW Herberg, Constituonal \& Administrative Law. (London: Cavendish Publishing Limited, 1995), hlm. 53. Berdasarkan prinsip yang dianut kaum liberalisme, pemerintah yang paling baik adalah pemerintah yang paling sedikit intervensinya dalam kehidupan masyarakat (the least govemment is the best govemment).

\&Pasal 4 ayat (1) UUD 1945. 
tugas dan wewenang pemerintahan yang secara konstitusional ada pada Presiden pribadi yang memiliki sifat prerogatif (di bidang pemerintahan) seperti Presiden sebagai pimpinan tertinggi angkatan perang, hubungan luar negeri, dan hak memberi gelar dan tanda jasa. ${ }^{9}$ Ruang lingkup kewenangan dan kekuasaan Presiden yang sangat luas ini, secara garis besar - sebagaimana yang berlaku pada kewenangan pemerintah pada umumnya - terbagi dalam dua bidang yaitu kewenangan di bidang pelayanan (besturing) dan pengaturan (regeling), yang dalam rangka melayani atau mengurus (besturen) dan mengatur (regelen) itu Presiden berwenang membuat peraturan perundang-undangan, mengeluarkan peraturan kebijaksanaan, dan berwenang membentuk lembaga-lembaga khususnya lembagá kementerian - yang disertai dengan kewenangan untuk mengangkat pejabat-pejäbatnya.

\section{Kedudukan Hukum Menteri}

Dalam penyelenggaraan tugas-tugas pemerintahan atau administrasi negara, pemerintah tidak menjalankan sendiri tugastugas tersebut, tetapi dijalankan oleh pembantu-pembantunya yaitu para menteri. Bahkan dapat dikatakan bahwa menterimenteri ini merupakan ujung tombak pelaksanaan tugas-tugas pemerintahan. $\mathrm{Di}$ dalam Pasal 17 UUD 1945 disebutkan bahwa; (1) Presiden dibantu oleh menteri-menteri negara; (2) Menteri-menteri itu diangkat dan diberhentikan oleh Presiden; (3) Setiap menteri membidangi urusan tertentu dalam pemerintahan; (4) Pembentukan, pengubahan, dan pembubaran kementerian negara diatur dalam undang-undang. ${ }^{10}$

Berdasarkan ketentuan pasal tersebut tampak bahwa menteri-menteri itu diangkat dan diberhentikan oleh Presiden sendiri. Menurut Moh. Kusnardi dan Bintan R. Saragih, karena menteri-menteri negara adalah pembantu-pembantu Presiden, maka kedudukannya adalah di tangan Presiden atau dengan kata lain menteri-menteri negara bertanggungjawab kepada Presiden. Dengan demikian menurut UUD 1945 yaitu berdasarkan Pasal 17, kabinetnya adalah kabinet presidensial di mana sebagai perdana menterinya adalah Presiden sendiri." Di dalam sistem kabinet presidensial, Presiden adalah pihak yang dilekati dengan kewenangan untuk menjalankan urusan

\footnotetext{
'Bagir Manan, Lembaga Kepresidenan (Yogyakarta: Pusat Studi Hukum UII Yogyakarta, Bekerja Sama dengan Gama Media, 1999), hlm. 122-128.

${ }^{10}$ Khusus Pasal 17 ayat (4) ada sedikit catatan dalam hal ini. Sepanjang sejarah pemerintahan Indonesia, persoalan kementerian selalu diatur dengan Keppres, karena memang kementerian itu merupakan persoalan internal lembaga kepresidenan. Adanya perubahan ini agaknya dillhami oleh tindakan Gus Dur, yang telah membubarkản Dëpartemen Sósiäl dan Departémen Penerängan dengan menggunakan Keppres, yang menimbulkän ketidakpuasan sebagiä̀n orang. Mungkin agar peristiwa ini tidak terulang, maka persoalan yang menyangkut pembentukan, péngúbahian dan pembubaran kementerian tidak lagi dianggap sebagai bagian dari "hak prérogatîf" Presiden, nämün mènjảdi "hak rakyat" untuk mèngatumya-melalui wakilnya di DPR.

"Moh. Kusnardi dan Bintân R. Saragih, Susunan Pembagian Kekuasaan Menurut Sistem UUD 1945 (Jakarta: Gramedia, 1989), hlï. $13 \%$
} 
pemerintahan. Dalam rangka menjalankan urusan tersebut, Presiden diberi kewenangan untuk membentuk kementerian dan mengangkat pejabat-pejabatnya. Lebih lanjut, lembaga kementerian yang dibentuk Presiden ini ada yang berbentuk Departemen dan ada yang berbentuk Non Departemen. Dari sini Presiden antara lain membentuk lembaga Sekretariat Negara, yang bertugas menjalankan kewenangan Presiden di bidang administrasi negara, dan membentuk lembaga kementerian yang bertugas untuk mensejahterakan rakyat dan mengentaskan kemiskinan, yakni berbentuk Menteri Koordinator bidang Kesejahteraan Rakyat dan Pengentasan Kemiskinan (Menko Kesra). Lembaga-lembaga yang dibentuk Presiden ini manjalankan kewenangan untuk dan atas nama Presiden. Dengan kata lain, dalam sistem presidensial para pejabat dari lembaga-lembaga kementerian yang bersangkutan tidak memiliki kewenangan mandiri. Oleh karena itu, dalam sistem ini tidak mengenal pertanggungjawaban menteri baik secara yuridis di hadapan pengadilan maupun secara politis di hadapan dewan perwakilan rakyat. Hal ini berbeda dengan yang berlaku pada sistem parlementer, yang menganut the doctrine of ministerial responsibility. Doktrin yang bertumpu pada prinsip bahwa kedudukan raja tidak dapat diganggu gugat atau raja tidak dapat dipersalahkan (the King can do no wrong, onschendbaarheis des Konings).

Khusus berkenaan dengan Menteri Sekretaris Negara, di dalam Pasal 1 Keputusan Presiden No. 104 Tahun 1998 tentang Kedudukan, Tugas, Fungsi, Susunan Organisasi dan Tata Kerja Sekretariat Negara disebutkan; "Sekretariat Negara adalah Lembaga Pemerintah yang bertugas memberi dukungan staf dan pelayanan administrasi sehari-hari kepada Presiden dalam menjalankan kekuasaan pemerintahan negara dan kepạda Wakil Presiden". Dalam Pasal 2 ayat (1) dan (2) disebutkan; "Sekretariat Negara dipimpin oleh Sekretaris Negara yang berkedudukan langsung di bawah dan bertanggungjawab kepada Presiden, apabila Sekretaris Negara diberi kedudukan Menteri negara, maka sebutannya adalah Menteri Sekretaris Negara".

Berdasarkan Keppres tersebut tampak bahwa kedudukan hukum Mensesneg adalah di bawah dan bertanggungjawab kepada Presiden. Kedudukan hukum demikian, berlaku juga untuk menteri-menteri lainnya, sebagai suatu konsekuensi dari sistem pemerintahan presidensial. Rumusan demikian ditilik dari struktur organisasi pemerintahan menunjukan bahwa menterimenteri dan juga Mensesneg merupakan bagian internal dari lembaga kepresidenan. Sebagai bagian internal, maka -dari perspektif hukum administrasi negara - akan segera diketahui hubungan hukum (rechtsbetrekking) yang terjadi antara menterimenteri termasuk Mensesneg dengan Presiden yaitu hubungan mandat (mandaat).

\section{Hubungan Hukum antara Menteri dengan Presiden}

Sebelum diketengahkan tentang hubungan hukum mandat, terlebih dahulu dikemukakan tentang cara-cara badan atau pejabat administrasi negara memperoleh kewenangan pemerintahan, yang dari sini akan segera diketahui hubungan hukum antara pemberi wewenang dengan penerima wewenang. $\mathrm{Di}$ dalam ilmu hukum administrasi ada yang dikenal dengan istilah atribusi (attributie) dan 
delegasi (delegatie). Menurut H.D. van Wijk/ Willem Konijnenbelt, ${ }^{12}$ "attributie : toekenning van een bestuursbevoegheid door een wetgever aan een bestuursorgaan" (atribusi adalah pemberian wewenang pemerintahan oleh pembuat undang-undang kepada organ pemerintahan), sementara "delegatie: overdracht van een bevoegheid van het ene bestuursorgaan aan een ander" (delegasi adalah pelimpahan wewenang pemerintahan dari satu organ pemerintahan kepada organ pemerintahan lainnya). Berdasarkan definisi ini, tampak bahwa wewenang yang diperoleh secara atribusi bersifat asli yang berasal dari undang-undang. Dengan kata lain, organ pemerintahan memperoleh kewenangan secara langsung dari redaksi pasal tertentu dalam suatu undang-undang. Dalam hal atribusi, penerima wewenang dapat menciptakan wewenang baru atau memperluas wewenang.yang sudah ada. Pada delegasi tidak ada penciptaan wewenang, yang ada hanya pelimpahan wewenang dari pejabat yang satu kepada pejabat lainnya. Sesudah mengetahui cara memperoleh kewenangan secara atribusi dan delegasi, lalu apa yang disebut mandat? $\mathrm{Di}$ dalam Algemene Wet Bestuursrecht (Awb), mandat berarti pemberian wewenang oleh organ pemerintahan kepada organ lainnya untuk mengambil keputusan atas namanya (pemberi mandat, mandans). ${ }^{13}$ Dengan kata lain, seperti disebutkan oleh H.D van WijkJ
Willem Konijnenbelt, "mandat terjadi ketika organ pemerintahan mengizinkan kewenangannya dijalankan oleh organ lain atas namanya" (mandaat, een bestuursorgaan laat zijn bevoegheid namens hem uitoefenen door een ander. ${ }^{14}$ Berkenaan dengan mandat ini, secara agak rinci, F.A.M. Stroink dan J.G. Steenbeek menyebutkan sebagai berikut:

"Bij mandaat is noch sprake van een bevoegdheidstoekenning, noch van een bevoegdheisoverdracht. In geval van mandaat verandert er aan een bestaande bevoegdheid (althans in formeel juridisch zin) niets. Er is dan uitsluitend sprake van een inteme verhouding, bij voorbeeld minister - ambtenaar, waar bij de minister de ambtenaar machtigt en/of opdraagt nemens hem bepaalde beslissingen te nemen, tenwill juridisch - naar buiten toedeminister het bevoegde en verantwoordelijke orgaan blijt. De ambtenaar beslist feitelijk, de minister juridisch". ${ }^{15}$

(Dalam mandat tidak dibicarakan mengenai penyerahan wewenang, tidak pula pelimpahan wewenang. Dalam hal mandat tidak terjadi perubahan wewenang apapun \{setidak-tidaknya dalam arti yuridis formal\}. Yang ada hanyalah hubungan internal, sebagai contoh Menteri dengan pegawai, Menteri mempunyai kewenangan dan melimpahkan kepada pegawai untuk megambil keputusan tertentu atas nama

\footnotetext{
${ }^{12}$ H. D. van WijkWillem Konijnenbelt, op. cit., hlm. 129. Bandingkan dengan B. de Goede. 1986.

Beeld van het Nederlands Bestuursrecht (Vuga Uitgeverij, 's-Gravenhage, 1986), hlm. 56.

${ }^{13}$ Afdeling I A.1.1 Awb 1992.

${ }^{14} \mathrm{H}$. D. van WijkWillem Konijnenbelt, loc. cit., him. 129.

${ }^{15}$ Stroink, F.A.M., en J.G. Steenbeek, op. cit., him. 46.
} 
Menteri, sementara secara yuridis wewenang dan tanggungjawab tetap berada pada organ kementerian. Pegawai memutuskan secara faktual, sedangkan Menteri \{memutuskan\} secara yuridis).

Berdasarkan beberapa pengertian ini, R.J.H.M. Huisman menyebutkan beberapa karakteristik dari mandat yaitu; Pertama, perintah untuk melaksanakan (opdracht tot uitvoering); Kedua, kewenangan dapat sewaktu-waktu dilaksanakan oleh pemberi mandat (mandans); Ketiga, tidak terjadi peralihan tanggungjawab; Keempat, tidak harus berdasarkan undang-undang (geen wettelijke basis vereist); Kelima, dapat tertulis, dapat pula secara lisan (kan schriftelijk, mag ook mondeling). ${ }^{16}$

Dari beberapa teori ini jelas menunjukan bahwa menteri hanyalah pihak yang menjalankan perintah baik perintah tertulis maupun lisan, bukan pemegang kewenangan yang sesungguhnya. Menteri -termasuk Mensesneg - hanyalah pelaksana perintah yang tidak dapat berbuat lain kecuali sekadar apa yang diperintahkan oleh Presiden. Karena menteri secara yuridis bukanlah pemegang kewenangan, maka konsekuensi yang muncul dalam hubungan mandat adalah bahwa menteri (mandataris) tidak memiliki kewenangan diskresi atau freies Ermessen dalam menjalankan tugas-tugas yang diperintáhkan oleh mandans. Kalaupun bentuk perintah yang diberikan Presiden itu masih samar atau ambigu, yang dapat dilakukan mandataris bukan menggunakan kebebasan melakukan penilaian (beoordelingsvrijheid) atau kebebasan melakukan interpretasi (interpretatiemarge) tetapi menanyakan langsung kepada mandans. Sebagai konsekuensi dari hubungan mandat, pelaksanaan tugas Mensesneg yang diberikan oleh Presiden masih berada dalam pengawasan penuh Presiden. Dalam hal ini Presiden dapat sewaktu-waktu memberikan petunjuk, menegur mandataris, menjalankan sendiri tugas yang telah diberikan tersebut, atau mengalihkan tugas tersebutkepada organ lain. Dalam konstruksi hubungan mandat ini, bila terjadi tuntutan hukum, maka tuntutan itu ditujukan pada pemberi mandat (mandans), selaku pemegang kewenangan, bukan pada penerima mandat (mandataris).

Terlepas dari kenyataan bahwa dalam praktek penyelenggaraan pemerintahan, menteri-menteri tersebut ada yang berbentuk menteri negara, menteri departemen, menteri non departemen, dan menteri muda, sistem pemerintahan presidensial - sebagaimana diisyaratkan Pasal 17 di atas-menempatkan menteri sebagai pihak yang berada di bawah dan bertanggungjawab kepada Presiden. Dengan kata lain, dalam sistem presidensial lembaga kementerian merupakan bagian internal dari lembaga kepresidenan, dengan hubungan hukum mandat. Berdasarkan konstruksi demikian, maka ketentuan Pasal 25 UU No. 43 Tahun 1999 tentang Perubahan UU No. 8 Tahun 1974 tentang Pokok-pokok Kepegawaian menjadi tidak logis atau tidak sejalan dengan teori pemberian atau pelimpahar wewenang pemerintahan. ${ }^{17}$

\footnotetext{
${ }^{18}$ R.J.H.M. Huisman, Algemeen Bestuursrecht, een Inleiding (Amsterdam: Kobra, 1976), hlm. 8.

${ }^{17}$ Pasal 25 UU No. 43 Tahun 1999 berbunyi; "Untuk memperlancar pelaksanaan pengangkatan, pemindahan, dan pemberhentian Pegawai Negeri Sipil, Presiden dapatmendelegasikan sebagian wewenangnya kepada Menteri atau pejabat lain".
} 
Meskipun secara konstitusional Indonesia menganut sistem presidensial, yang menempatkan Presiden selaku pihak yang dilekati wewenang penyelenggaraan pemerintahan dan karenanya ia memikul pertanggungjawaban, namun dalam hal-hal tertentu sistem ini tidak sepenuhnya dianut secara konsisten. Hal ini terbukti dengan adanya pemberian wewenang secara atribusi kepada menteri. Sekadar untuk menyebutkan sebagian contoh, simaklah beberapa pasal atribusi berikut ini:

Pasal 20 ayat (3) dan (4) UU No. 23 Tahun 1997 tentang Pengelolaan Lingkungan Hidup menyebutkan; (3) Kewenangan menerbitkan atau menolak permohonan izin sebagaimana dimaksud pada ayat (1) berada pada Menteri; (4) Pembuangan limbah ke media lingkungan hidup sebagaimana dimaksud pada ayat (1) hanya dapat dilakukan di lokasi pembuangan yang ditetapkan oleh Menteri. Pada Pasal 29 ayat (4) disebutkan bahwa jumlah beban biaya sebagaimana dimaksud pada ayat (3) ditetapkan oleh Menteri.

Dalam Pasal 17 ayat (3) UU No. 41 Tahun 1999 tentang Kehutanan disebutkan, "Pembentukan unit pengelolaan hutan yang melampaui batas administrasi pemerintahan karena kondisi dan karakteristik serta tipe hutan, penetapannya diatur secara khusus oleh Menteri". Pada Pasal 33 ayat (3) disebutkan, "Pengaturan, pembinaan, dan pengembangan pengelolaan hasil hutan sebagaimana dimaksud pada ayat (2) diatur oleh Menteri", dan dalam Pasal 79 ayat (3) disebutkan bahwa "ketentuan lebih lanjut sebagaimana dimaksud pada ayat (2) diatur oleh Menteri".

Beberapa pasal tersebut secara jelas menunjukan adanya pemberian kewenangan secara atribusi kepada menteri. Karena sebagian menteri mendapatkan kewenangan atribusi, yang berarti memperoleh kewenangan langsung dari pembuat undang-undang (wetgever), lalu bagaimana dan kepada siapa kewenangan menteri ini dipertanggungjawabkan? Bukankah dalam sistem presidensial tidak dianut doktrin pertanggungjawaban menteri? Lebih lanjut, ada redaksi pasal dalam undang-undang yang menunjukan konstruksi yang tidak sejalan dengan prinsip pertanggungjawaban dalam sistem presidensial, yaitu terdapat dalam Pasal 38 ayat (5) UU No. 41 Tahun 1999 tentang Kehutanan yang berbunyi; "Pemberian izin pinjam pakai sebagaimana dimaksud pada ayat (3) yang berdampak penting dan cakupan yang luas serta bernilai strategis dilakukan oleh Menteri atas persetujuan Dewan Perwakilan Rakyat". Ketika menteri memberikan izin pinjam pakai sebagaimana disebutkan dalam pasal tersebut dengan tanpa persetujuan DPR atau menteri tersebut dalam menggunakan kewenangan tidak sejalan dengan kebijakan DPR, apakah DPR dapat menuntut atau meminta pertanggungjawaban menteri? Ataukah DPR menuntut pertanggungjawaban kepada Presiden, selaku "atasan" menteri, sementara kewenangannya diberikan kepada menteri? Apakah Presiden boleh mengabaikan pertanggungjawaban terhadap penyalahgunaan penggunaan kewenangan menteri yang diperoleh secara atribusi, dengan alasan Presiden tidak memiliki kewenangan tersebut? Bila Presiden dapat mengabaikan pertanggungjawaban, bagaimana dengan prinsip "concentration of power and responsibility upon the President" yang dianut dalam sistem presidensial? Beberapa pertanyaan ini menunjukan bahwa pelaksanaan dan pertanggungjawaban pemerintahan dengan 
sistem presidensial yang dianut di negeri ini masih menyimpan sejumlah persoalan hukum.

\section{Pertanggungjawaban Pelaksanaan Kewenangan Pemerintahan}

Secara teoretik, tanggung jawab mengandung dua aspek, yaitu aspek intemal dan aspek eksternal. Pertanggungjawaban yang beraspek internal, hanya diwujudkan dalam bentuk laporan pelaksanaan kekuasaan. Pertanggungjawaban dengan aspek ekstemal, adalah pertanggungjawaban terhadap pihak ketiga, apabila dalam melaksanakan kekuasaan itu menimbulkan suatu derita atau kerugian. ${ }^{18}$ Dalam negara hukum demokratis, pertanggungjawaban ini muncul dalam dua dimensi; dimensi hukum dan dimensi politik. Pertanggungjawaban dalam dimensi hukum mengandung arti bentuk pertanggungjawaban dalam penggunaan kewenangan apakah sesuai atau tidak dengan hukum yang dibuktikan melalui proses peradilan di hadapan hakim, sedangkan pertanggungjawaban dalam dimensi politik dilakukan dalam bentuk "laporan" penggunaan kewenangan di hadapan rakyat. Pertanggungjawaban politik di hadapan rakyat ini diperlukan sehubungan dengan penggunaan kewenangan yang berasal dari rakyat, yang sudah dituangkan dalam bentuk undang-undang. Artinya rakyat -melalui wakilnya di Parlemen - mempunyai hak untuk menilai apakah penggunaan kewenangan oleh pemerintah itu sesuai atau tidak dengan undang-undang yang merupakan kristalisasi kemauan dan kehendak rakyat. Sudah barang tentu dua dimensi pertanggungjawaban ini akan memunculkan dua konsekuensi bagi pemegang kewenangan, konsekuensi hukum dan konsekuensi politik.

Telah disebutkan, salah satu prinsip dalam negara hukum demokratis adalah bahwa setiap tindakan hukum pemerintah atau administrasi negara harus didasarkan pada kewenangan yang berikan oleh undangundang. Pemberian kewenangan ini dapat tejadi secara atribusi maupun delegasi. Lebih lanjut, tindakan-tindakan hukum dari pemerintah ini, yang secara garis besar bertindak dalam bidang pengaturan dan pelayanan, selanjutnya dituangkan dalam bentuk instrumen yuridis seperti peraturan-peraturan (regelingen), keputusan-keputusan (besluiten), ketetapanketetapan (beschikkingen), dan peraturan kebijaksanaan (beleidsregel). Oleh karena tindakan pemerintah itu tertuang pada instrumen yuridis, maka pertanggungjawaban publik pemerintah akan berkaitan dengan bagaimana pembuatan dan penggunaan instrumeninstrumen tersebut, serta apa akibat-akibat hukum yang muncul darinya. ${ }^{19}$

\footnotetext{
${ }^{18}$ Sowoto, "Kekuasaan dan Tanggung Jawab Presiden", Disertasi, Universitas Airlangga. Surabaya 1990, hlm. 80

${ }^{19}$ Berdasarkan hukum positifyang beriaku di Indonesia, pertanggungjawaban hukum melalui proses peradilan terhadap penggunaan kewenangan yang sudah dituangkan dalam bentuk instrumen yuridis dilakukan melalui Mahkamah Agung jika itu berbentuk peraturan-peraturan dan keputusan-keputusan, sesuai dengan ketentuan Pasal 26 UU No. 14 Tahun 1970 yang telah dirubah dengan UU No. 35 Tahun 1999 tentang Ketentuan-ketentuan Pokok Kekuasaan Kehakiman dan Pasal 31 ayat(1)UU No. 14 Tahun 1985 tentang Mahkamah Agung, sedangkan jika berbentuk ketetapan-ketetapan, maka ditempuh melalui administratif beroep dan PTUN, sesuai dengan
} 
Dalam hukum administrasi negara, pertanggungjawaban (verantwoordelijk), yakni verplicht tot het afleggen van verantwoording en tot het dragen van event toerekenbare schade (desgevorderd), in rechte of in bestuursverban"20 (kewajiban untuk memikul tanggungjawab dan kewajiban untuk menanggung kerugian yang muncul fjika diperlukan\}, baik dalam hukum maupun dalam hubungan pemerintahan), dibebankan kepada pemegang kewenangan. Di atas telah disebutkan tentang cara-cara pemberian dan pelimpahan kewenangan, yang dari situ akan diketahui siapa yang harus memikul pertanggungjawaban. Kewenangan yang diperoleh secara atribusi akan meletakan tanggung jawab intem dan ekstem sepenuhnya berada pada penerima wewenang (atributaris), sementara yang diperoleh secara delegasi maka tanggung jawab yuridis tidak lagi berada pada pemberi delagasi (delegans) tetapi beralih pada penerima delegasi (delegataris). ${ }^{21}$. Dalam hal pelaksanaan kewenangan yang didasarkan pada hubungan mandat, beban tanggungjawab tetap berada pada pemberi mandat, karena pada hubungan mandat ini hakikatnya tidak terjadi peralihan atau pelimpahan wewenang namun sebatas pelaksanaan perintah dari mandans. Dalam sistem presidensial hubungan hukum antara
Presiden dengan menteri-menteri adalah hubungan mandat; oleh karena itu yang dibebani untuk memikul pertanggungjawaban adalah Presiden, selaku pemegang kewenangan. Dengan demikian, Mensesneg bukanlah pihak yang harus memikul pertanggungjawaban terhadap penyelenggaraan urusan pemerintahan, karena ia hanyalah pihak yang menjalankan perintah, bukan pemegang kewenangan.

\section{Simpulan}

Di dalam negara hukum setiap tindakan pemerintahan harus didasarkan pada kewenangan yang diperoleh dari undangundang atau peraturan perundang-undangan yang berlaku, baik secara atribusi maupun delegasi. Kewenangan yang diperoleh secara atribusi dan delegasi akan menempatkan pemegang kewenangan sebagai pihak yang memikul tanggungjawab terhadap peggunaan kewenangan. Kewenangan yang dijalankan berdasarkan hubungan mandat tidak menempatkan pelaksana kewenangan sebagai pihak yang memikul tanggungjawab, karena pada konsep mandat tidak terjadi peralihan atau pelimpahan wewenang. Mandataris atau penerima mandat hanyalah pihak yang melaksanakan perintah,

ketentuan UU No. 5 Tahun 1986 tentang PTUN. Adapun untuk peraturan kebijaksanaan, hukum positif di Indonesia tidak atau belum memberikan jalan keluar mengenai boleh tidaknya mengajukan gugatan terhadapnya. Agaknya para pembuat undang-undang di Indonesia masih begitu kukuh berpegang pada konsep "de rechter niet op de stoel van de administratie gaan zitten" yang muncul dari prinsip "the separation of power, machtenscheiding" warisan abad pertengahan.

${ }^{20}$ S.J. Fockema Andreae, Rechtsgeleend Handwoordenboek (J.B. Wolters' Uitgeversmaatschappij n.v., Groningen, 1951), hlm. 308.

${ }^{21}$ Ridwan, Hukum Administrasi Negara (Yogyakarta: Ull Press, 2002), hlm. 77. 
sementara kewenangan masih tetap berada pada pemberi mandat. Berdasarkan sistem presidensial yang dianut di Indonesia, kedudukan menteri berada di bawah dan bertanggungjawab kepada Presiden, karena itu hubungan hukum yang terjadi adalah hubungan mandat. Dalam hubungan ini menteri bukanlah pemegang kewenangan (geen de drager van bevoegdheid), menteri hanyalah pihak yang bertindak untuk dan atas nama Preśiden, oleh karena itu menteri - termášuk Mensesnëg - tidak memikul pertänggungjawaban (geen de drager van verantwoordelijkheid). Wallahu a'lam bi alshawab.

\section{Daftar Pustaka}

Bagir Manan. Lembaga Kepresidenan. Yogyakarta: Pusat Studi Hukum UII Yögyakarta Bekerja Sama dengan Gama Media، 1999.

Belinfante, A.D., et.al. Beginselen van Nederlanidse Staatsrecht. Alphen aan den Rijn, 1983.

De Goede, B. Beeld van het Nederlands Bestuursrechit. Vuga Uitgeverij, 'sGravenhage, 1986.

Fockema Andreae, S.J. Rechtsgeleerd Handwoordenboek. J.B. Wolters' Uitgeversmaatschappij n.v., Groningen, 1951.
Foulkes. Introduction to Administrative Law. Fourt Edition. London Butterworts, 1976.

Irving Stevens. Constitutional \& Administrative Law. Third Edition. Pitman Publishing, 1996.

Le Sueur. AP., dan JW Herberg. Constituonal \& Administrative Law. London: Cavendish Publishing Limited, 1995.

Moh. Kusnardi dan Bintan R. Saragih. Susunan Pembagian Kekuasaan Menurut Sistem UUD 1945. Jakarta: Gramedia, 1989.

Nicolai, P., et. al. Bestuursrecht. Amsterdam, 1994.

Ridwan. Hukum Administrasi Negara. Yogyakarta: Ull Press, 2002.

Sowoto. "Kekuasaan dan Tanggung Jawab Presiden." Disertasi. Universitas Airlangga, Surabaya, 1990.

Stroink, F.A.M., en J.G. Steenbeek. Inleiding in het Staata-en Administratief Recht. Samsom H.D. Tjeenk Willink, Alphen aan den Rijn, 1985.

Ten Berge, J.B.J.M. Besturen Door De. Overheid. Deventer: W.E.J. Tjeenk Willink, 1996.

Van Wijk. H.D./Willem Konijnenbelt. Hoofdstukken van Administratief Recht. Uitgeverij Lemma BV. Utrecht, 1995.

\section{$\infty$ ๑)}

